\title{
THE HERMENEUMATA (PSEUDODOSITHEANA) AND THEIR DIDACTIC USE*
}

\author{
BOŘIVOJ MAREK
}

\begin{abstract}
The article presents a basic characteristic of Latin-Greek didactic texts called the Hermeneumata Pseudodositheana and, in particular, their colloquia. It offers several examples of the colloquia with a brief commentary and an analysis focused particularly on their didactic dimension. In the second part of the paper, attention is given to the distinction between an active and passive approach to teaching classical languages from both theoretical and practical viewpoints and to finding reference points between the method of the ancient colloquia and modern methods. In conclusion, a theoretical justification of using the colloquia when teaching Latin in a natural / direct method is presented, complemented by several suggestions how these texts may contribute to making Latin courses more efficient and attractive.
\end{abstract}

Keywords: direct method of a language teaching; natural method / approach to language teaching; Hermeneumata Pseudodositheana; colloquia; Greek and Roman school system

Ego adulescentulos existimo in scholis stultissimos fieri, quia nihil ex his, quae in usu habemus, aut audiunt aut vident. ${ }^{1}$ Petron. 1, 3

\section{Natural method and the Hermeneumata Pseudodositheana}

The "natural method" of teaching a foreign language can be defined, for example, in the following words: "Speech is perceived as a skill which is acquired by people intui-

* This paper, dealing with the method and characteristic of the ancient teaching colloquia from a set of the Hermeneumata, is based on a part of the dissertation in progress titled "Usage of Latin Discourses in Lessons of Latin".

1 "This is the reason, in my opinion, why young men grow up such blockheads in the schools, because they neither see nor hear one single thing connected with the usual circumstances of everyday life" (translation Allinson 1930). 
tively through imitating and reinforcing models from their environment. ... Everyone should, according to this method, learn language in the same way, as a child learns his / her mother tongue. And the best is to learn it in the environment where the language is spoken, or from a native speaker. The foreign language is the only one spoken in the class and everyday topics, culture, literature and history of the nation speaking this language is discussed."2 From the natural approach, the so-called "direct method" was developed in the $19^{\text {th }}$ century as a reaction to the "grammar-translation" approach. It is based on the following principles: ${ }^{3}$

1) Language is perceived as a means of communication.

2) Great emphasis is placed on speaking abilities and correct pronunciation.

3) Intuitive imitation plays an important role (often without further explanation of grammatical rules).

4) Teaching is performed via dialogue and asking questions.

5) Subject matter is first presented orally, using pictures - only later on is written presentation applied (translation and the use of mother tongue in general should be restricted).

6) Information about culture, history, and literature is an integral component of teaching.

Considering these core points of the direct / natural approach and based on investigating the instruments offered in one of the first "course books" 4 of a foreign language produced by Western culture, I conclude that the instruments envisaged by the course book lead to very similar goals and didactic methods, formulated in quoted definitions. The course book in question is a collection of bilingual (i.e. Greek-Latin) didactic tools and texts known as the Hermeneumata Pseudodositheana. ${ }^{5}$ Most of the texts included in the collection of the Hermeneumata (hereinafter $H$. ${ }^{6}$ were published by Georg Goetz in the third volume of Corpus Glossarium Latinorum in $1892 .^{7}$

The textual tradition of $H$. is highly complicated, and I will therefore list here only the resulting segmentation of the whole of the body to individual $H$. as introduced by Eleanor

Malkusová (2012: 59), my translation.

Cf. Malkusová (2012: 59).

4 The term "Lehrbuch" as a classification for the Hermeneumata is used, for example, by Tagliaferro (2003: 51) and Ricucci (2015: 20).

5 These teaching resources gained the attribute Pseudodositheana since in some manuscripts (in MS Sangall. 902, for example) they were included in the Greek-Latin grammar book by Greek scholar Dositheus Magister ( $4^{\text {th }}$ century AD) and they were ascribed from the $16^{\text {th }}$ to the $19^{\text {th }}$ centuries to his authorship. Dositheus wanted to teach Latin to the Greek-speaking inhabitants of the Roman Empire, but his authorship of the Hermeneumata has been reliably disproved. Dositheus lived in the $4^{\text {th }}$ century $\mathrm{AD}$ and the period of origin of some parts of the Hermeneumata had been, according to scholars, earlier. The addition of Dositheus' work to the Hermeneumata in manuscripts was most probably caused by the fact that the teachers who used the Hermeneumata for teaching used Dositheus' grammar book as well and vice versa; cf. Dickey (2012: 35), Flammini (2004: VI-VII), Korhonen (1996: $101, \mathrm{n} .1)$. The original hypothesis is remembered now only by the expression "false authorship" in the title. Other authors, in regards to the Hermeneumata, have not been noted.

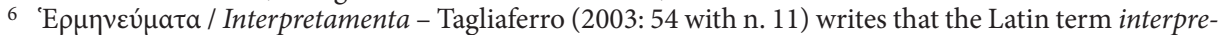
tamentum can refer to, for example, translation. Gell. V, 18, 7 uses it in the same way, too. However, the Greek term $\dot{\varepsilon} \rho \mu \eta ́ v \varepsilon v \mu a$ as a terminus technicus is a specific designation of a textual type and distinguishes $H$. from other types of genres and texts.

7 Detailed description of this extensive work is given by, for example, Dionisotti (1982: 85-86). 
Dickey: ${ }^{8}$ H. Monacensia, ${ }^{9}$ H. Einsidlensia,${ }^{10}$ H. Leidensia, ${ }^{11}$ H. Stephani, ${ }^{12}$ H. Montepessulana, ${ }^{13}$ H. Amploniana or Hygini H. ${ }^{14}$ H. Bruxellensia, ${ }^{15}$ H. Vaticana, ${ }^{16}$ and H. Celtis or H. Vindobonensia. ${ }^{17}$

The Hermeneumata - Interpretamenta usually consist of the following parts:

1) Greek-Latin glossaries in roughly alphabetical order (in the ancient understanding).

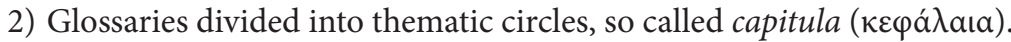

3) The Colloquia - didactic texts describing scenes from ordinary everyday life.

4) Bilingual texts of various types designed for reading practice. ${ }^{18}$

Chronological determination of these texts is not straightforward. It is possible that individual parts could have been added in various periods; they could have undergone a certain development outside the corpus prior to being reinserted in their new form. ${ }^{19}$ Texts and other components were further developed and added, but it is not unlikely that some of the sections originated already in the $1^{\text {st }}$ century AD. The majority of $H$. were probably gathered and used as a complex teaching resource no earlier than in the $3^{\text {rd }}$ and $4^{\text {th }}$ centuries AD. ${ }^{20}$

\section{The colloquia from a set of the Hermeneumata}

$H$. consist of miscellaneous assemblages of elements mentioned before (glossaries, colloquia, texts). In this paper, I will focus entirely on the so-called colloquia (hereinafter coll.). The reason for this is that coll. have a very peculiar didactic quality. Having examined coll. in various versions of $H$., E. Dickey concludes that there are actually seven dif-

8 Dickey (2012: 17-20). Classifications of $H$. by researchers differ slightly; cf. Dionisotti (1982: 87), Korhonen (1996: 103).

9 Goetz (1892: 119-220).

10 Goetz (1892: 223-279).

11 Goetz (1892: 3-72).

12 Goetz (1892: 347-390 and 438-487).

13 Goetz (1892: 283-343).

14 Goetz (1892: 72-94).

15 Goetz (1892: 393-421).

16 Goetz (1892: 421-438).

17 Dionisotti (1982) published the colloquium (below, see "The colloquia from a set of the Hermeneumata") from $\mathrm{H}$. Celtis, but an edition of this collection in its entirety is not yet available. A complete edition is being prepared by Rolando Ferri.

18 For example Aesopic fables, Delphic precepts, philosophers' answers, Hyginus' genealogy, adaptation of the Trojan War etc.; cf. Dickey (2012: 24-30).

19 See e.g. Korhonen (1996: 113-118) and Dickey (2012: 37-39).

20 Miraglia (2009: 10). The development of $H$. can be, according to some researchers, related to Diocletian's reforms (end of the $3^{\text {rd }}$ century AD) or even to the earlier Constitutio Antoniniana (212 AD). In this period, the number of inhabitants on the East of the Empire desiring to learn Latin could have increased; cf. Rochette (1997: 116-126; 2008: 87) and Adams (2003: 635-637). The fact that there are basically no links to Christianity in coll. and $H$. as such serves as evidence of their relatively ancient origin as well; cf. Dionisotti (1982: 90-91). 
$H$. as such and their coll. specifically have been, in spite of the enormous intellectual and philological work performed by Georg Goetz in his edition, overlooked by scholars for a very long time. Goetz's edition does not include all of the materials available today. ${ }^{22}$ Moreover, the research in this field had notably developed and it was necessary to establish new text amendments and a new commentary. This task was achieved in a very comprehensive and enormously precise way by Eleanor Dickey. She published two volumes between 2012-2015, containing a critical edition of all available coll. which included an English translation (the first ever translation of the coll.), an in-depth linguistic and factual commentary, and an extensive and erudite introduction. She examines the issues of the origin, development, and purpose of $H$., and mainly of their coll. ${ }^{23}$

Coll. ${ }^{24}$ are Greek-Latin "mirror" texts, so to speak, consisting of short, monologue-type narratives or dialogues. In manuscripts, they are often headed by the words

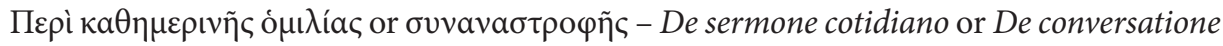
cotidiana. The language we find in this structure is, therefore, sermo quotidianus. ${ }^{25}$ It is colloquial language which differs significantly from literary materials commonly used at schools. It is also necessary to say that this language, in the case of Latin, is dissimilar to those literary texts that we usually consider to be examples of colloquial or vulgar Latin, so to speak the language close to this class, i.e. Plautus' comedies, Cena Trimalchionis by Petronius or some passages from Apuleius' Asinus aureus. These works are, after all, purely literary and so they contain many artistic touches: they play with the phonetic quality of words; they intentionally include morphosyntactic allusions; and they present deliberate and elaborate choices of lexis, etc. ${ }^{26}$ Coll. do not exhibit such features. Here we find a raw form of everyday language, without such beautifications and artistic undertone. ${ }^{27}$ The situation is similar for Greek. To some extent, the language is close to, for example, the Greek of the New Testament, ${ }^{28}$ but it contains many more deflections from normative grammar and it is, as in the case of Latin, unpolished.

Whom were the coll. intended to serve and in which way? There are many hypotheses and reflections on this question as well, many of which concern the Greek-Latin bilin-

21 Dickey (2012: 20).

22 H. Celtis (namely its coll.), named after German humanist and poet Conrad Celtes, were included in the paper by Dionisotti (1982).

23 For more information about this edition (namely its first volume) see the review by Corbeill (2013).

24 In contemporary terminology, one can call them colloquia scholica; cf. Ricucci (2015: 20).

25 The linguistic definition of "common speech" or "commonly spoken language" based on Krčmová, Chloupek (2002: 193) is "functionally defined form of national language whose structural content can be different and often also mixed, depending on specific circumstances of the origin and perception of communication. This common speech is primarily spontaneous and spoken and serves ... common daily communication" (my translation).

26 Cf. Tagliaferro (2003: 64).

27 However, it is necessary to acknowledge that the text of coll. was assembled with an obvious didactic purpose, so in a certain way it does deviate from a completely authentic form of "commonly spoken language".

28 Dionisotti (1992: 96). Dionisotti also adds that if one language was a translation of the other (which is definitely not the case, see further), the translator would probably have been Greek with not quite sufficient knowledge of Latin. This is because there are more deflections from the formal standards and more mistakes in the Latin part. 
gualism of the Roman Empire, especially in the $3^{\text {rd }}$ and $4^{\text {th }}$ century AD. ${ }^{29}$ I will present only one very plausible conclusion, supported both by Korhonen ${ }^{30}$ and Dickey: ${ }^{31}$ if we look at the contents of individual parts of the coll., it is obvious that they present the description of daily events from morning to evening ( $a$ b exordio lucis usque ad vesperum)..$^{32}$ We read the descriptions of waking up, getting up, the way to school, time spent at school (from a pupil's point of view), but also descriptions of the daily activities of an adult - going to court, to a bank, enforcing a loan, visiting a bathhouse or spending time at a feast, etc. Everything is then concluded with the evening preparations for going to bed. If the coll. were part of a children's course book, the question presents itself whether children expressed a desire or an actual need to learn about the proceedings of court inquiries or to examine how a wife tells off her husband for getting drunk in public and thus embarrassing her. ${ }^{33}$ Another related question arises, namely why would the Romans among whose crucial contributions to European civilization was the development of their legal system, be more deeply interested in Greek legal terminology, which is in the coll. just a calque of Latin terms. ${ }^{34}$ This leads us to the conclusion that in the sets of coll., we can distinguish two subsets.

\section{Didactic determination and types of the colloquia}

A) Study texts designed for pupils and students, in which the narrator is typically a boy going to school. These texts served (with high probability) Roman children in the Western part of the Empire in order to study both Greek and Latin. Korhonen and Dickey call this section of coll. "Schoolbook".35

B) Study texts designed for adults, often in the form of dialogues with adult participants. Topics cover the public life, major life events, administrative, financial, and judicial activities. This type of text was apparently used in the Eastern part of the Empire, in Greek and other non-Latin speaking regions (such as Egypt). With the help of the Greek part of the text, Greek people (and via Greek also other residents speaking a foreign language) learned Latin. It is not possible to suppose, especially speaking about this type of text, that the reason was idealistic - to gain knowledge of Roman literature and culture. The motivation was most probably absolutely superficial - the need to master just enough working knowledge of Latin to be able to hold positions in the management of the Empire, ${ }^{36}$ to be able to understand the world of Roman

29 In this respect, we may refer to many studies, for example, Adams (2003), and Rochette (1997; 2008).

30 Korhonen (1996: 105-108).

31 Dickey (2012: 44).

32 Below, see example 5) "Before leaving for school".

33 Below, see example 6) "A wife tells off her drunk husband".

34 Below, see example 4) "Higher grade schools".

35 Korhonen (1996: 105) and Dickey (2012: 44).

36 Dickey (2012: 5) mentions a nice parallel of the relationship of French people to English. Until recently, they resisted learning foreign languages but now, to compete in a global economy, they have to learn languages extensively, especially English. 
law, and to find employment in the Roman army ${ }^{37}$ or administration. Teaching with the help of these coll. was performed in a different way than teaching children and at the core was, first of all, the memorization of needed phrases. Therefore, the term „Phrasebook“ may be appropriately used here. Sets of phraseologies also existed independently from the extant corpus of coll., to which they were later added.

It is to some extent still unclear if Latin was taught through Greek, or if it was the other way round. Dickey ${ }^{38}$ thinks that both language mutations could have been created simultaneously since it is evident that those syntactic and other linguistic elements to which there is no parallel in the other language were deliberately left out (for example, Greek infinitive with the article, constructions with $\pi \rho$ ív etc. and regarding Latin, for instance, gerunds and gerundives).

\section{The colloquia in Roman and Greek school curriculum}

Coll. and all the collection of $H$. together with a number of bilingual glossaries were likely a component of the school curriculum. Passing it was required especially for Greeks desiring to learn Latin or, alternatively and in the bilingual mutation, for Latin pupils and students. ${ }^{39}$ This hypothetical curriculum can be reconstructed when these factors are considered: 40

1) Greek students first learn the Latin alphabet and the basic elements of the Latin language, whereas Romans learn to write and read the letters of the Greek alphabet. Work with syllables and syllabary follows. ${ }^{41}$

2) A process follows which we can call nomenclatura, with the pupils learning to name objects around them using appropriate expressions.

3) Simultaneously with point 2), children learn basic morphology. At first they try to master frequently used expressions without having a fixed scheme or paradigm.

4) They then memorize phrases and expressions from everyday communication, using miscellaneous exercises, variations, questions, etc. Coll. focusing on conversatio cottidiana represent a helpful tool in this enterprise. The pupils learn to converse: their language scope is directed to lower levels of communication and to informal language.

5) In the next phase, the pupils start working with easy coherent texts, such as fables, tales, and other stories (see the last part of $H$.). These are followed by very easy exercises modelled after activities, which aim to train grammatical and rhetoric abilities, the so-called progymnasmata. ${ }^{42}$

37 As a member of the Roman army, the individual would eventually receive Roman citizenship and benefits connected to it.

38 Dickey (2012: 49).

39 Debut (1984) and Dionisotti (1982: 86-87).

40 According to Miraglia (2004: 226-227); cf. Ricucci (2015: 23-24), and especially Dickey (2015b: 31-51).

41 See e.g. Johnson (2011).

42 Penella (2011), for example, deals with the role of progymnasmata in tuition and their role in the rhetorical education more generally. Baxter (2008) examines the practical usage of progymnasmata 
6) Texts become more challenging and involve reading of Virgil, Cicero's speeches, and other authors. Romans work with Homer's eposes and with Greek orators while learning Greek. Students are not yet, however, equipped with sufficient linguistic knowledge to read these authors without any difficulties. The teacher accompanies them and provides them with a word-for-word translation (ad litteram). The pupils obtain knowledge about the semantic effect of a particular expression and about a particular change of meaning in the context of a given sentence.

7) Students who want to continue their education on a higher level focus on studying commentaries on poems and narrative prose and they also start using more complex rhetorical progymnasmata. Such training was considered sufficient preparation for engaging in public affairs.

\title{
Examples of texts of the colloquia ${ }^{43}$
}

\author{
1) Preface to Coll. Celtis - Dickey (2015a: 165, title and \\ preface) $)^{44}$
}

De cottidiana conversatione.

Conversatio, usus cottidianus, debet dari omnibus pueris et puellis, quoniam necessaria sunt minoribus et maioribus, propter antiquam consuetudinem et disciplinam. Sic incipiam scribere, ab exordio lucis usque ad vesperum. ${ }^{45}$

The first excerpt represents one of the typical headings and one of the annotations of coll. at stake. It is an unequivocal definition of a purpose, i.e. to discuss everyday topics in a lively manner, by conversation, and by dialogue. The education should be realised by means of a description of everyday events, thus exactly in the way which uses an active

when teaching composition in modern languages and Stramaglia (1996) examines the progymnasmata's influence on the ancient novel (cf. n. 78).

43 Dickey comments in detail on each coll. both from the linguistic point of view and from the factual one. Therefore, I do not intend to focus on imitating her work, regardless of the limited space of this paper, and I will focus instead on commenting on the didactic aspects in particular. I adopt the texts of her edition, but I make some amendments to ensure better understanding and orientation - capitalizing initial letters of sentences, punctuation, quotation marks for direct speech, division of replicas in dialogues (usually with speakers marked A and B), etc. For the sake of brevity, I usually present only the Latin versions of the coll. as examples. However, in example 4), I quote the Greek as well to emphasize the comparison and usage of both languages. The translation is adopted from Dickey's edition as well. The editor herself executed a very challenging work in analysing individual coll. and their language tradition and in comparing Greek and Latin version. She added accents and aspiration to the Greek for a more comfortable reading of the texts. She presents the text variations in a very extensive apparatus.

44 Dickey advocates division of the text into columns to create Greek and Latin parallels and points out the advantages of such a division even in the ancient times themselves. Despite this, I order the text in consecutive lines to save space; cf. Dickey (2012: 55). Regarding the layout of two versions of text, a comparable method of text reading was introduced by J. Hamilton (1769-1831) who popularized interlinear translations of Greek and Latin classics. For more see Blum (2008). However, it is apparent that interlinear translation, or a co-existence of two texts as regards coll., did not gain acceptance and that the above-mentioned mirror layout was preferred.

45 "The [?] chapters concerning daily conversation. Conversation, everyday usage, ought to be given to all boys and girls, since they are necessary for both younger and older, on account of ancient custom and learning. Thus let me begin to write, from the beginning of daylight until evening." 
approach to language instruction abundantly, not only in modern languages but to a certain extent often in the classical as well (see below for the analysis of a natural method, and the introductory definition of this paper). Focus on naming things surrounding us (nomenclatura), is also a common basic element of a lively style of language teaching.

Here we read an interesting dedication: pueris et puellis. Education is for both boys and girls. A. C. Dionisotti welcomes this remark and comments: "Pleasing inclusion, unique in the colloquia ... Social status, rather than sex, probably determined whether a child learnt at home or at school." 46 However, since we do not find any similar reference in any other coll. and nor it seems that a girl would be a protagonist of any of the coll., the word could have been added in later centuries. It is also not very likely that education of girls would somehow significantly develop in late antiquity. ${ }^{47}$

The expression like minoribus et maioribus can be compared with an example 2), when it also speaks about older and younger pupils and students. ${ }^{48}$

The words propter antiquam consuetudinem et disciplinam can suggest a long tradition of coll. and indicate that this coll. is a latter-day continuation of this ancient tradition. On the other hand, according to E. Dickey it can be only a later added statement informing us that we have something to do with old ancient languages. ${ }^{49}$

Ab exordio lucis usque ad vesperum is a phrase common in coll., whose task is to describe a whole day or some event from the beginning to the end. This approach could be also connected with the general ancient rhetorical didactic practice which is, according to Quintilian, to proceed systematically in precisely defined steps, without leaving anything out or skipping it. ${ }^{50}$ It also seems likely that the words about a whole-day effect were added later, once the coll. was fixed in its final compound form. As has been already said above, two parts can be distinguished in coll. - a "Schoolbook" and a "Phrasebook", i.e. a passage concerning a child (morning lessons at school) and a section devoted to an adult (mostly afternoon work and other activities in the city and in the society). It follows from this that none of the protagonists would have been able to cover the whole day. ${ }^{51}$

\section{2) Description of school activities (Coll. Celtis) - Dickey (2015a: 170-177, 18-39e) $)^{52}$}

Eo foras ad auditorium calculatoris (notarii, Graeci, Latini, oratoris). Intravi in scholam et dixi: 'Ave, magister (ave, praeceptor).' Et ille me resalutat. Dat mihi manuale et iubet me legere apud se paginas quinque; et legi certe et nobiliter. Tunc alio dedi. Postea redeo ad subdoctorem. Saluto illum et condiscipulos, et illi me resalutaverunt. Tunc sedi in loco meo (meo loco) super scamnum (aut sellam, aut gradum, aut scamillum, aut cathedram). Sedente me porrigit puer meus scriniarius pugillares et thecam graphiorum, praeductale, tabulam et lupinos. (Deduco, duco, computo, ...). Deleo et praeduco ad superpostum, et scribo et

46 Dionisotti (1982: 107).

47 Cf. Dickey (2015a: 197).

48 See also n. 58.

49 Cf. Dickey (2015a: 197).

50 Cf. Bloomer (2011: 111) and Quint. Inst. X, passim.

51 Cf. Dickey (2015a: 197-198).

52 Number of lines in this excerpt and in the following ones corresponds with the numbers in Goetz's edition. 
ostendo doctori meo. Et laudavit me quod bene scripsi. Relego quod scripsi ad distinctum. Recito. 'Recitavi prior te!' 'Mentiris!' 'Si verum dicis <...>' Dixit mihi meus paedagogus: 'Eamus domum, ut possimus ire ad Graecum et ad grammaticum.' Deinde ad ceroma dimittimur ad Latina studia et ad Graeca. Intravimus scholam Graeci et auditorium grammatici. Edisco scripta mea. Si paratus sum, statim reddo; sin autem, iterum lego. (Praelego, relego ...). Accepi lectionem (versus, glossulas). Explanatur mihi ignotus liber aut ignota lectio. Expositio traditur. Accipio locum, et alii mecum extemporalem, ceteri accuratum reddunt. Minores interpretamenta et syllabas, sermonis declinationem, artem omnem, sermonem exercent apud subdoctorem: casus nominum, genera nominum, numeros, figuras, vocabula, vocabula per litteras, litteras, vocales et semivocales et mutas; dividunt, suspendunt, elevant. Deinde universa pertranseunt, sed et capitula nominum, partes orationis octo. Sic fit silentium. Eunt priores ad magistrum; legunt lectionem de Iliade, aliam de Odyssia. Accipiunt locum (suasoriam, controversiam, historiam, comoediam, narrationes, omnem industriam orationis, causas Troici belli, materiam recitationis, recitationes; actiones Tullianas, Maronem, Persium, Lucanum, Statium, duo bella, Terentium, Sallustium, tres comoedias, Theocritum, Thucydidem, Demosthenem, Hippocratem, Xenophontem et Cynicos). Tunc revertitur quisque, in suo loco considunt. Quisque legit lectionem sibi subtraditam; alter scribit, alter meditatur. In ordinem recitant quisque pro posse; si quis bene recitavit, laudatur; si quis male, coercetur. Fit dimissio: dimittimur circiter horam septimam. ${ }^{53}$

53 I quote here the school part of the coll. in its entirety, even though it is rather lengthy. It is important to see the whole passage in its complexity. Translation: "I go outside to the lecture hall of the mathematics teacher (the shorthand writer, the Greek [teacher], the Latin [teacher], the orator). I entered the school and said: 'Hello, teacher (hello, instructor).' And he returns my greeting. He gives me the book-stand / the textbook / handbook and orders me to read five columns in front of him; and I read accurately and excellently. Then I gave [the book-stand / the textbook / the handbook] to another [student]. Afterwards I go away to the teacher's assistant. I greet him and my fellow students, and they returned my greeting. Then I sat in my place (my place), on top of the bench (or seat, or stair, or stool, or chair). When I am seated, my boy, who carries my writing, implements hands [me] writing tablets and a case of styluses, ruler, tablet, and lupins. (I subtract, I calculate, I reckon ...). I rub out [the previous contents of my tablets] and I rule lines following the model, and I write, and I show [the results] to the person teaching me because I wrote well. I read aloud what I wrote, with proper pauses. I recite. 'I recited before you did.' 'You're lying!' 'I'm not lying!' 'If you're telling the truth ...' My paedagogus said to me: 'Let's go home so that we may be able to go to the Greek [teacher] and to the grammarian.' Then we are dismissed to the wrestling-ground, to Latin studies and to Greek [studies]. We entered the school of the Greek [teacher] and the lecture-hall of the grammarian. I learn my [assigned] writings thoroughly. If I am ready, I produce [them] at once; but if not, I read [them] again. (I read in front of the class, I read aloud ...). I received a reading (verses, obscure words). An unknown book or an unknown reading is explained to me. An explanation is given. I receive a passage, and others along with me render it extemporaneously, the rest render it after careful preparation. The smaller [children] practise hermeneumata and syllables, the inflection of the word, the whole grammar book, conversation in front of the teacher's assistant: the cases of nouns, numbers, compositional status, words, words in alphabetical order, letters, vowels and continuants and stop consonants; they pronounce with proper divisions, suspensions, [and] accentuation. Then they go through everything, also the lists of nouns classified by subject, the eight parts of speech. So then there is silence. The more advanced students go up to the teacher, they read a reading about the Iliad, another about the Odyssey. They receive a passage (a suasoria, a controversia, a history, a comedy, stories, all diligence of rhetoric, the causes of the Trojan war, the basis for a recitation, something to repeat back; the speeches of Cicero, Virgil, Persius, Lucan, Statius, the two wars, Terence, Sallust, the three comedies, Theocritus, Thucydides, Demosthenes, Hippocrates, Xenophon, and the Cynics). Then each one returns, they sit down in their own place. Each one reads the reading assigned to him; one writes, another practises. They recite in order, each one according to his ability; if someone has recited well, he is praised; if someone [has recited] badly, he is punished. The dismissal happens: we are dismissed around the seventh hour.' 
The pupil describes the process of his coming to school and staying there. ${ }^{54}$ In the text, various alternatives are given at particular places (usually in brackets) to enrich pupils' vocabulary and knowledge about individual semantic groups. This list of synonyms or options expands in some places to a large extent. ${ }^{55}$ We thus see a clear focus on lexicum and increasing word-stock, i.e. another meeting point with the practice of the natural method. Vocabulary is taught in connection with its practical usage.

There are brief dialogues among pupils and between a pupil and a slave accompanying the pupil to school (paedagogus) inserted in the text, which give the whole narration vivacity and interactivity. It is again something which is frequently used in lessons of living languages and which could be to a great benefit used also in the current teaching of Latin.

An interesting point is the list of teaching aids and also the list of activities performed by pupils in individual "subjects". We can see here the division between senior (priores) and junior (minores) pupils as well. Some sequences recur in the coll., and this probably indicates that this coll. was assembled from several other coll. ${ }^{56}$ For example, the children are dismissed several times from school. The first and last section (not included in the cited example, in Goetz's edition lines 40-42) describe ludus litterarius, the first level of school, ${ }^{57}$ then the middle section describes school with grammaticus where some more demanding elements of rhetoric were introduced to the pupils. ${ }^{58}$ Here we read, among other things, about suasoriae and controversiae, which were already greatly advanced rhetorical exercises following fourteen preceding progymnasmata and leading to the preparation for oral declamation. ${ }^{59}$

In addition, the words Accipio locum, et alii mecum extemporalem, ceteri accuratum reddunt deserve attention. Two groups of students work here with a text. One group, as it seems, works with a text without preparation, the other with preparation. It is difficult

54 An analysis of this extract is provided by Dionisotti (1982: 120-121), outlining a possible practice of a certain grade of Roman school.

55 I do not quote the lists in their full length because they would occupy too much space.

56 Dionisotti (1982: 84), Dickey (2015a: 160).

57 Cf. Cribiore (2001: 38).

58 Dickey (2015a: 216) writes that from line 30a, starting with the word Intravimus it is a different type of school than in the first part. On the other hand, it is true that some children really attended several different schools during a day. It thus does not have to be a synthesis of two coll.; cf. Dickey (2015a: 216) and Quint. Inst. I, 12, 13-14 and II, 1, 12-13. Generally, it is also agreed that the order of grades, ludi magister - grammaticus - rhetor, was not fixed. Divergences existed and the whole system was apparently very flexible, reflecting the needs and abilities of the child. Basics of some disciplines could be learned by children already at home; cf. Dionisotti (1982: 121) and especially Stramaglia (1996: 101) who writes: "E emerso infatti con piena chiarezza che, a fronte del persistere di uno schema ideale tripartito dell'educazione (insegnamento elementare, grammaticale, retorico), la scuola antica fu nei fatti una realtà socialmente segmentata, geograficamente condizionata e storicamente flessibile ..." The flexibility of the Roman school system was already described by Suet. Gramm. 25, 8: Ratio docendi nec una omnibus nec singulis eadem semper fuit, quando vario modo quisque discipulos exercuerunt. "But the same mode of teaching was not adopted by all, nor, indeed, did individuals always confine themselves to the same system, but each varied his plan of teaching according to circumstances" (translation Thomson 1909).

59 Cf. Baxter (2008: 36). Stramaglia (2010: 114-119) derives his conclusions from the text of Iuv. 7 (especially verses 150-154) about the miserable fate of a rhetoric teacher, and from our passage of Coll. Celtis, and he envisages how the different stages of preparation to declamation (reading, listening, memorizing) and its final performance proceeded. Stramaglia pays attention chiefly to whether the pupils were sitting or standing at each stage of the process. 
to say exactly what they did with the text. Based on the common procedure at schools, the possible activities in the class may have included reading (or translation), as well as paraphrasing and interpreting the texts. ${ }^{60}$

One very valuable item is the reading list, which includes both Latin and Greek items. A. Stramaglia remarks that it is "una testimonianza d'ineguagliata ricchezza, ancora poco sfruttata."61

One can read the words interpretamenta, vocabula per litteras, capitula nominum in this excerpt. That means pupils really engage in activities which should be, according to the research (see enumeration of parts of $H$.), included in $H$.

E. Dickey points out that the conclusion of the whole of Coll. Celtis was probably assembled in the Western area of the Empire because a pupil reappears in epilogue who was a "narrator" in the introduction. ${ }^{62}$ It looks as if the role of "Schoolbook" and coll. in teaching process in Western part of the Empire should be emphasized, for the coll. served here as one of the elementary aids for the instruction of the youngest pupils. One can thus imagine that the final version could have originated for example in Gaul (Burdigala, Massilia?). This would correspond to the assumption of A. C. Dionisotti that similar coll. could have been well known and "rewritten" by the poet Ausonius (see commentary following example 5)).

Regarding our knowledge of the ancient teaching methods, mentions of mathematics are particularly interesting - since the information on this topic is otherwise very patchy. ${ }^{63}$

The cited example shows an apparent focus on the overall sociability of learning, on the collective of children, teachers, subdoctores, on face-to-face communication in general. This feature is considered key by Quintilian. ${ }^{64}$ From the viewpoint of modern linguodidactics, this conception contributes to the development of social competence, i.e. to the development of the ability to work with other children which can result in reinforcement of trust in their own power when realizing communication.

This excerpt from the coll. can be used in present-day Latin lessons in several ways: from a linguistic point of view it offers an interesting and wide stock of words related to the school environment; from a cultural-historical viewpoint it represents a canon of Greek and Latin reading (with a reservation mentioned in n. 61) and provides information about the practice of Roman or Greek education systems. The conception of lexicum corresponds with the practice of an "oral approach", or the so-called "situational approach", where lexical material is not given in an isolated form but rather in context, here even in a very authentic ancient context. The explanation of vocabulary occurs on the basis of introduction to a situation where the expression at stake can be used. Many

60 For more see Dickey (2015a: 217).

61 Stramaglia (1996: 105). The listing of authors is truly remarkable. As we can see, a well-known quadriga auctorum - Terence, Sallust, Virgil, and Cicero - is included; cf. Hagendahl (1967: 384, 479, 692-693). On the list, there are also authors whose works were not a common part of lists of compulsory readings; cf. Cribiore (2001: 192-204). It is thus possible that this list of authors could have gone through the same process as other lists and listings of words in the coll., i.e. the gradual enriching of the register by the adding of new items, in this case authors regardless of whether they have actually been read in schools; cf. Dickey (2015a: 222).

62 Dickey (2015a: 158).

63 Cf. Cribiore (2001: 180-183).

64 Cf. Bloomer (2011: 111) and e.g. Quint. Inst. II, 3, 10-11. 
words related to education do not tend to be a part of commonly taught terms at a grammar school these days, but the authenticity of such a set of vocabulary can be clearly appreciated, from which one can move to other similar and familiar semantic areas. Information about reading and other school practices can, to a certain extent, contribute to the development of sociocultural competence in current students, i.e. by obtaining knowledge about the cultural peculiarities of ancient Latin- and Greek-speaking schools and those who frequented them, or about the ways they behaved in specific situations.

\section{3) Being accepted by a teacher (Coll. Montepessulanum) - Dickey (2015a: 95-97, 2a-2i)}

D: 'Praeceptor, ave! Quoniam volo et valde cupio loqui Graece et Latine, rogo te, magister, doce me.' M: 'Ego faciam, si me attendas.' D: 'Adtendo <te> diligenter.' M: 'Quoniam ergo video te huius rei, hoc est eius interpretationis quae dicitur Latina, cupientem, demonstrabo tibi, fili, quoniam non est cuiuslibet hominis deprehendere, sed docti et ingeniosi esse doctrinam. Propter hoc etiam tibi magis qui nescis nihil disputare exponam. Opus ergo tibi est quae praecipio; auditus, memoria, sensus, usus cotidianus artificem facit. $<\ldots>$ hoc tibi. Si praestiteris mercedes, potes discere. Duae ergo sunt personae quae disputant, ego et tu. Tu es qui interrogas, ego respondeo. Ante omnia ergo lege clare, diserte. '65

This text apparently demonstrates the pupils' understanding of what is required for their education: motivation, diligence, attention, talent, and continuous work on their tasks.

However, there is no mention about what Quintilian considered the main purpose of education: "Quintilian's greatest theoretical claim is that his process renders the child moral and makes the boy a man." 66 A teacher is depicted here as a rather practical man who wants to teach only a gifted student who is likely to require less work and who will pay tuition fees. For it is necessary to pay the teacher properly for his services. Seneca the Elder also apparently talks about the miserable salary of teachers giving instruction in both languages (duas res) and directly uses the word hermeneumata. ${ }^{67}$

From the didactic point of view, there is again a focus on the productive aspect of language (valde cupio loqui Graece et Latine; qui nescis nihil disputare). Naturally, this fact cannot be adequately compared to the current situation where the languages in question are dead, although according to some scholars, active work with a language inspires in students a sense of the meaning of their actions: "In practical terms, the lack of active skills in Latin is not likely to be much of a difficulty. Yet even in the modern languages,

65 "P: 'Teacher, hello! Since I want and exceedingly desire to speak in Greek and in Latin, please, teacher, teach me.' T: 'I shall do [so], if you pay attention to me.' P: 'I am paying attention to you carefully.' T: 'Therefore, since I see you desirous of this thing, that is, of this speech that is called Latin, I shall show you, son, that it is not for just anyone to master it, but that it is the attainment of [one who is] well educated and naturally intelligent. Indeed on account of this especially to you, who do not know how to speak at all, shall I explain. Therefore you have need of what I recommend; [for] hearing, memory, understanding, [and] daily practice make an expert. ... this to yourself. If you provide payment, you can learn. So, there are two persons who converse, I and you. You are the one who asks, [and] I answer. So, first of all read clearly [and] distinctly.'”

66 Bloomer (2011: 111-112) and Quint. Inst. XII, 1, 1.

67 Sen. Contr. IX, 3, 14; cf. also Dickey (2012: 53, n. 143). 
it is not only practicality which causes programs to begin with descriptions of surroundings, counting, and conversing. These basic skills are precisely what give students a sense of the meaningfulness of the language they are studying. Without this grounding of the ancient language in their own reality, college students all too frequently begin and end their study of Latin with the feeling that it is a difficult code which they must decipher, rather than a language which naturally expresses meaning." 68

In the words usus cotidianus artificem facit the necessity of intensive care with language is yet again emphasized in order to be able to properly penetrate it. In today's practice, this didactic principle relates in particular to the connection of the effectivity of natural method with a number of lessons or with frequency of its usage. One of the crucial principles of the natural approach is the principle of "comprehensible input". Based on this, a pupil naturally and quickly acquires and develops a target language, if the language incentives which he / she is exposed to only slightly exceed the level of proficiency the pupil already possesses. If, on the contrary, one's contact with the language is insufficient or interrupted, and the lessons are few and far between, the pupil then necessarily does not find any continuity in his / her studies and the natural method can fail.

Final reference to the dialogical form of instruction only underlines what has already been noted, for example in relation to Quintilian's principles of teaching in excerpt 2).

\section{4) Higher grade schools (Coll. Montepessulanum) - Dickey} (2015a: 98, 5a-5b)

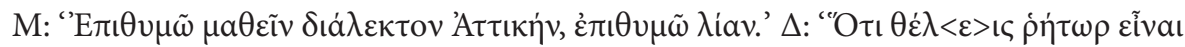

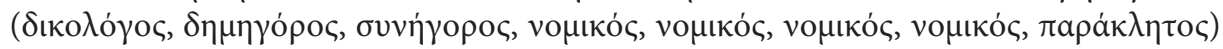
$<\ldots>>$

D: 'Cupio discere sermonem Atticum, cupio valde.' M: 'Quoniam vis orator esse (causidicus, dicentarius, actor, iuris studiosus, iuris peritus, iuris consultus, iuris prudens, advocatus) $<\ldots>>69$

This is one of the instances of a short coll. referring to legal practice. It may be an introductory exercise for a candidate interested in a career in the legal system and it is very likely that a similar text was also included in the teaching materials for adults ("Phrasebook").

It is hard to say whether this short excerpt does not actually consist of two parts. If students want to learn Greek (Attic dialect), that does not necessarily mean that they want to do so with an obvious intention to study law. It is possible that the explicit reference to the Attic dialect (because elsewhere, it is always talked generally about Greek) means that a student is already a speaker of a different Greek dialect and wants to learn a classic branch of Greek in which the most important rhetorical works originated, to secure a higher quality of education. ${ }^{70}$

68 Deagon (1991: 60).

69 'S: 'I desire to learn the Attic dialect, I desire [it] exceedingly.' T: 'Since you want to be an orator (pleader, popular orator, speaker, legal expert, legal expert, legal expert, legal expert, advocate) ...'”

70 Cf. Dickey (2015a: 120). 
Conversely, in the second part it looks like this coll. is meant for Greeks who want to learn Latin to master legal education which was connected more to the Roman world than the Greek.

It is interesting to compare the Latin and Greek legal terminology. The Latin terminology is superior, due to its more fully developed semantic differentiation. This may be the proof that here the target language was Latin for Greek-speakers. Latin legal terms or the names for different people dealing with law changed their meaning over time and were often synonymous. ${ }^{71}$ At the time of the late Empire, iuris consultus or iuris prudens was an excellent jurist, who had the status of possessing the ius respondendi, while the term iuris peritus denoted a less significant jurist and one who operated mainly in the provinces. Iuris studiosus is probably only a synonym for iuris peritus. Other legal professions mentioned here were de facto expressions for a barrister, an attorney representing a client. Advocatus (or causidicus) is more likely an advocate, while actor is a prosecutor (although this term might have denoted also an advocate). While the word orator could have signified any party, it would most probably be an advocate. The term dicentarius is very rare and it is not clear which legal function it denotes.

We cannot say much about didactic aspects of this short text. However, it is obvious that this coll. provides the opportunity to learn various synonyms.

\section{5) Before leaving for school (Coll. Monacensia- Einsidlensia) - Dickey (2012: 104-105, 2a-2f)}

Ante lucem vigilavi de somno; surrexi de lecto, sedi, accepi pedules, caligas; calciavi me; poposci aquam ad faciem; lavo primo manus, deinde faciem lavi; extersi. Deposui dormitoriam; accepi tunicam ad corpus; praecinxi me; unxi caput meum et pectinavi; feci circa collum pallam; indui me superariam albam; supra induo paenulam. Processi de cubiculo cum paedagogo et cum nutrice salutare patrem et matrem. Ambos salutavi et osculatus sum, et sic descendi de domo.72

This text focuses on teaching new vocabulary. The focus on word-stock and building on real surroundings are common practice when teaching live languages and have proved very useful time and time again. ${ }^{73}$ One can once more show the active work with wordstock. J. Wills writes that "learning vocabulary is a basic prelude to reading, and that oral Latin drills and activities are demonstrably the best way to do that."74

Short and clear lines that we see here are also indispensable in the first phase of the teaching process: "The key pedagogical strategy will be to make use of many short, simple

71 Dickey (2015a: 121).

72 "Before daylight I awoke from sleep; I got up from the bed, I sat down, I took gaiters, boots; I asked for water for [my] face; I wash [my] hands first, then I wash [my] face; I dried [myself], I took off [my] night-clothes; I took a tunic for my body; I put on my belt; I anointed my head and combed [my hair]; I put around my neck a mantle; I put on an outer garment, a white one, [and] on top I put on a hooded cape. I went out of the bedroom with [my] paedagogus and with [my] nurse, to greet [my] father and mother. I greeted them both and kissed them, and then I came down out of the house."

73 E.g. Deagon (1991: 63): “Simple classroom exercises like 'Qu'est-ce que c'est?' are easily adaptable to Latin: Quid est? Est mensa, chartula, liber, stilus ..."

74 Wills (1998: 32). 
sentences for a much longer time than we usually do. Our leading pedagogical maxim ought to be "Practice comprehension!" toward a consistently phrase-based one in which words and forms are always learned in some sort of verbal context, facilitating the students' mental acts of "direct" understanding."75

Information about everyday domestic life is also valuable. For example, the habit to kiss one's parents (but also one's teacher, as written in the other coll.) is, until this day, characteristic for almost all Romance nations. J. Corbeill offers a witty comment on the topic of everyday life: "But it is the immediacy of the narrative and the homeliness of the subject matter that most attracts attention; scholars of ancient Greece and Rome spend so much time reading about souls that we are taken by surprise - and consequently delighted - at the mention of soles."76 The focus on soles is truly remarkable. A child puts on his shoes even before washing. Dickey has a quite prosaic explanation that soles were a necessary protection against a temperature shock, which a child would have experienced in the morning on the cold stone floors. ${ }^{77}$

This coll. and others similar to it led A. C. Dionisotti to form a hypothesis that such a school text, likely well-known, inspired the poet Ausonius ( $4^{\text {th }}$ century AD) to write a set of poems titled Ephemeris. ${ }^{78}$ This assumption can be used for linking language-facts teaching and the literature of late antiquity. If the hypothesis on Ausonius' inspiration is true, and everything implies it is, it also suggests that the manuals were used monolingually as well, for Ausonius was hardly interested in Greek. ${ }^{79}$

\section{6) A wife tells off her drunk husband (Coll. Celtis) - Dickey} (2015a: 186-187, 66a-68b)

$\mathrm{U}$ : 'Quis sic facit, domine, quomodo tu, ut tantum bibis? Quid dicent qui te viderunt talem? Quod numquam foris cenasti tam aviditer? It a hoc decet sapientem patrem familias sui negotii (qui aliis consilia dat) semet ipsum regere? Non potest turpius nec ignominiosius evenire quam heri gessisti!' M: 'Me certe valde pudet.' U: 'Quid dicunt alii in absentia tua? Infamiam maximam tibi cumulasti. Accidit ad haec grandis denotatio de tali intemperantia! Rogo te, ne postea tale facias. Sed modo numquid vomere vis? Et miror quae passus es.' M: 'Nescio quid dicam, ita enim perturbatus sum, ut rationem nulli possim reddere. '80

75 Pavur (1998).

76 Corbeill (2013).

77 Dickey (2012: 140).

78 Dionisotti (1982). This theory is developed and supported by arguments in a study by Pucci (2009). It even seems that this is not the only inspiration which $H$. provided to authors of literary texts. Stramaglia (1996) deals with the relation between $H$. and their coll., and more likely progymnasmata, or even declamation with "narrativa", i. e. with the texts of ancient novels.

79 Pucci (2009: 53).

80 "W: 'Who acts like this, sir, as you do, that you drink so much? What will they say, those who saw you in such a condition? That you never dined out so greedily? Is this a fitting way for a prudent paterfamilias who minds his own business (who gives advice to others) to conduct himself? It is not possible [for things] to happen more shamefully or more ignominiously than you acted yesterday.' H: 'I certainly am very much ashamed.' W: 'What do others say in your absence? You have accumulated great infamy for yourself. In addition to this, great censure [of you] has occurred as a result of such intemperance. Please, in the future don't do such a thing. But now do you want to vomit? And I'm amazed what has become of you.' H: 'I don't know what to say, for I have been so upset that I can't give an explanation to anyone.' 
It is difficult to decipher to whom this extract was addressed. It might have been used as an exemplum, taking examples from day-to-day life. This may have been useful for potential Greek students who learned Latin for utilitarian social reasons. However, it is as likely that the text served as a moral lesson for children. This interpretation directs us again to Quintilian and his main goal, i.e. the moral upbringing of a pupil. ${ }^{81}$

While Dickey prefers to hypothesise that the drunk man is being rebuked by his wife (or his friend), ${ }^{82}$ in my opinion, this scene draws similarities with Plautus' comedies, when the scolding of a degraded master was performed by his slave.

It is again possible that the scene is actually composed in two parts. Certain incoherencies in the text would suggest so: heri gessisti compared to Sed modo numquid vomere vis. It is however also possible that this is a situation when paterfamilias comes home in the early hours after a prolonged stay at a feast. ${ }^{83}$

This text, and others similar to it, may have been performed as a drama. This is very likely and probably applied to the majority of dialogical coll. Short scenic performances are then another coveted and popular element of active approach to language teaching. There is not much space for them in lessons today but their usefulness for the fixation of the word-stock, phrases and some basis of thinking in Latin has been proved since the time of Comenius and, owing to coll., since ancient times. ${ }^{84}$

\section{Teaching methods in ancient times}

Before approaching the evaluation of coll. from a set of $H$. as a teaching aid promoting the principles of the natural method, let us have a brief look at teaching methods in antiquity.

Ancient authors reveal information about other "didactic methods" used in their times and those of their own ancestors: Herodotus ${ }^{85}$ describes how pharaoh Psamtik I, who was interested in foreign languages and linguistics, sent selected Egyptian boys to Ionian and Carian merchants to learn Greek. ${ }^{86}$ This is an example of a method now known as "full immersion", which is certainly one of the more extreme applications of the living method. Nowadays, without native speakers, it would naturally be harder to enforce this practice in the case of Greek and Latin, but perhaps it should not be dismissed. ${ }^{87}$

81 See note 66 and commentary on the example 3).

82 Cf. Dickey (2015a: 244-245).

${ }^{83}$ For more see Dickey (2015a: 244).

84 Cf. e.g. Bexley (2015). Bexley (2015: 214) writes: "Although often marginal to current classroom practice, dramatic reenactment can enhance students' understanding of Plautus' and Terence's plays in deep and vital ways, from recreating and thereby exploring the technical aspects of theatre to situating play scripts in their social, historical or ritual contexts." A proof that the demand for involving theatrical practices in Latin education increases is, for example, hosting an international conference "Fabula agitur! Pratiques théâtrales et artistiques, oralité et apprentissage des langues et cultures de l'Antiquité. Histoire, esthétique, didactique" (2015), the topic of which was the use of theatre and other artistic practices in lessons of classical languages.

85 Herodot. II, 154, 2.

86 Similar comments can be found in works by other authors as well. These testimonies are elaborated by Tagliaferro (2003: 65).

87 Cf. schools, where the instruction is given solely in Latin (Vivarium novum in Rome or Schola nova in Belgium), and also many Latin summer schools and other long-term project conducted in an envi- 
Scholars dealing with ancient education quote with great delight Saint Augustine's experience from his school days. He describes two didactic approaches: a strict and pedantic Greek teacher who apparently did not motivate his pupils and was unable to explain to them the usefulness of the subject. This teacher insisted that Augustine should know Homeric Greek and demanded it by force. On the other hand, there was the natural and pleasant learning of Latin through the means of conversation with nannies and domestic slaves. ${ }^{88}$ Two famous terms are mentioned related to teaching: meticulosa necessitas and libera curiositas. It is obvious that he had been learning Latin from early childhood, whereas with Greek he started later, and consequently, the methods were different. As has already been mentioned above, this factor, i.e. time and age, when students start to learn is also closely related to the selection of the appropriate methods. For older students, who are properly motivated, more analytical methods bring good results, and perhaps they are more apt than potentially open-ended and non-obligatory uses of the natural method.

A significant overview of pedagogical principles and approaches is available to us in particular thanks to Quintilian and his Institutio oratoria. Quintilian seems to be a very perceptive and experienced teacher and a good psychologist of a child's soul. ${ }^{89} \mathrm{His}$ teaching method is based on rhetorical principles and designed to bring up not only a skilful speaker but also a morally firm and noble man. It is not possible to describe here the whole of Quintilian's teaching, but several aspects can be mentioned at least: in the introductory phase of teaching a child it is not good to focus on grammar (Sed nihil ex grammatice nocuerit nisi quod supervacuum est). ${ }^{90}$ At that stage, he does not abstain from using games and plays in education, ${ }^{91}$ taking approach which is not dissimilar to the natural method and which is also called for in the coll. from $H$.

\section{Active vs. passive approach in classical languages education}

Having studied the teaching set of $H$. and especially their coll., we find that these teaching practices fit very well into the definitions of the natural / direct teaching method

ronment where Latin is spoken (although it is Latin more or less the literary sort, not the authentic, informal).

${ }^{88}$ It is hard to say to what extent Augustine learned Latin as a mother tongue or as a second language right from his early childhood, for his mother's tongue was not Latin but Punic (or maybe Berberic since Monica was of Berberic origin); cf. Adams (2003: 213-245). The conditions for learning a foreign / native tongue are obviously not the same. For more about Augustine's impressions of the lessons see Ricucci (2015: 25-27) and Miraglia (1996: 9-10); cf. Aug. Conf. I, 14, 23.

89 See Bloomer (2011).

90 Quint. Inst. I, 7, 34: "But grammar will do no harm except where it is extraneous" (translation Bloomer 2011). Furthermore Bloomer (2011: 134) adds that "too much grammar, like a beating or the over zealous imitation of the elder Cato, produces a hesitant, fearful, or thin child and style. These are moral consequences as well since the child will not wish to study and to speak. Quintilian (Inst. I, 8, 18-19) disapproves of the pedantry of grammarians which will only impede the children's ingenia."

91 Quint. Inst. I, 3, 11: Sunt etiam nonnulli acuendis puerorum ingeniis non inutiles lusus, cum positis invicem cuiusque generis quaestiunculis aemulantur. "Some games are not unuseful for sharpening the boys' wits, as when they strive with one another to answer trifles of every kind posed them one after another" (translation Bloomer 2011). And cf. also Bloomer (2011: 126, n. 31). 
described in the introduction. Let us briefly revisit the principles of these methods, and thus also of the coll., in particular, in the contrast to grammar-translation and analytical methods, both of which being predominantly passive. In general, advocates of almost all known methods usually agree on the fact that the primary goal of learning, especially in lower grades, is to gain, as soon and as fast as possible, the ability to read original texts: "Latin pedagogy continues to focus on one of the skills, reading, while adding a second skill usually reserved for the most advanced stages of modern language instruction: detailed analysis of grammar." ${ }^{2}$ Educational researchers differ in opinion on the best method for gaining the ability to read. Perhaps, the question to ask here may be "What is meant by the ability to read?"

Advocates of an analytical approach primarily believe that students best gain this ability by translating Latin sentences word by word or as a puzzle or aenigma. ${ }^{93}$ "In fact, Latin is much more than a set of puzzles to be struggled through, bit by bit. It is not some kind of grammatical algebra. It is a "language"."94 Grammar-translation method is close to the analytical approach and emphasizes that classical languages are dead and thus it is not appropriate to approach them as modern languages, i.e. on the basis of the four-skills approach (speak, hear, write, and read). ${ }^{95}$ To translate a Latin text is, according to other researchers, very counterproductive, and most students are needlessly burdened by it and the procedure does not bring effective results. ${ }^{96}$ According to the structural linguist André Martinet, during a translation a line (or any other translated part of the text) is transferred as a whole from scratch to a second language. He calls this process "repensée phrastique". It is thus necessary to translate textual sequences (sentences) as a whole and

92 Deagon (1991: 59).

93 Hansen (2000: 174) evaluates this approach and his verdict is not positive: "Students who persist, sometimes through their college years, in reading Latin primarily by "solving" each sentence through a "subject, then verb, then object, etc." hunt-and-gather system may never become comfortable reading quickly and confidently at sight, and they are certainly less attentive to matters of style than those who are able to receive information in the order and manner in which Latin authors present it." Dickey (2015b: 40) writes that "there are no ancient counterparts of the efforts expended by modern Latin teachers exhorting students to pay attention to the endings and take the nominative rather than the word that happens to come first as the subject of the sentence."

94 Pavur (1998).

95 Neither of these methods, however, entirely excludes a productive work with language and there is a place for translation from the mother tongue to Latin and Greek. Especially in the latter half of the $19^{\text {th }}$ century and at the beginning of $20^{\text {th }}$ century it was common for a text to be re-translated "in the style" of a certain classical author. This practice earned severe criticism at the end of $20^{\text {th }}$ century, in particular from Ball, Ellsworth (1989 and 1992).

96 Deagon (2006: 33) examined the "cognitive style" ("learning style"), i.e. the nature and type of students with regard to how they digest information and how they learn. It has followed from her article that the grammar method in Latin instruction is close to students who are field independent and who practice operation learning. "Field independent" means that a student is more focused on details of studied matter and is not greatly influenced by external factors of tuition like the atmosphere in class or opinions of classmates; "operation learning" means that a student derives from rules and guidelines where he builds an overall picture of the studied material. Its concrete details are also important for him. According to the research, however, there are less than 10 percent (!) of such students. Students of different cognitive styles are able to achieve good results with grammar-analytical method. However, these are only a minority of those most talented. The rest of students, in fact a vast majority, are more or less lost. 
not word-by-word as is often the case in lessons, when pupils translate from Latin in order to understand. ${ }^{97}$

A second approach, inherent to methods accepting and often welcoming active and productive usage of language, even in the case of dead languages, conceives the ability to read a Latin text and tries to teach students, at least to some extent, to think in the target language. "There is a special intoxicating challenge in confronting an unannotated Latin text and a very satisfying intellectual experience in making the words make sense. Ideally, translation should not be necessary at all; the meaning should rise out of the text straight to your brain without the mediation of a "mother tongue" equivalent." 98

The natural method does not want to work with a language other than the original and wants to deal with it in all its productive and receptive forms. On the coll. and other ancient examples (see below) one can note that this approach was already firmly rooted in antiquity and that it has been successfully used for centuries. ${ }^{99}$ It then went on to a "humanistic" approach and after an intermezzo of strictly philological and grammatical conception of education, it has found numerous supporters since the end of $19^{\text {th }}$ century. Claude Fiévet writes that procedures and methods which originated on the basis of structural linguistics have long been lacking in the teaching of classical languages and that these methods can be very well used based on the example of living languages. ${ }^{100}$

Disputes between advocates of the active and passive approaches still continue and there are teachers who go to great lengths to avoid the active approach. They consider it bizarre, ridiculous and futile. According to them, it takes a student away from real knowledge and it seduces him to unpurposeful plays and superficial treatment of a sterile, unauthentic form of the language. ${ }^{101}$

${ }^{97}$ Cf. Fiévet (2015: 313 with n. 8). Fiévet (2015: 312) also points out the danger that an awareness of the whole meaning of the line may be lost if an extreme analytical method is used: "Nam cum sententia accurate discinditur et in partes minutissimas summa diligentia consecatur, quae scriptor ad cogitationem enuntiandam una eademque mentis contentione in unum coniunxit et conglobavit, ea dirumpuntur et distrahuntur; atque ex hoc discessu ipso consequitur ut cogitatio evanescat dissoluta."

${ }^{98}$ Levine (2006: 51-52); and also Markus, Ross (2004: 82): "Bypassing the native language and achieving vivid visualization by interacting directly with the target language is the ultimate goal ..." Anhalt (2006) underlines and proves a known fact in her article that any translation of a text is not and cannot be on the level of the original. Or, to quote an old Italian proverb: "Traduttore, traditore".

${ }^{99}$ See for example Comenius' principle (from the Ianua linguarum reserata of 1631): Omnis lingua usu potius discitur quam praeceptis, id est, audiendo, legendo, relegendo, imitationem manu et lingua temptando quam creberrume. "Each language is learned rather by using than by rules, which means by listening to it as much as possible, by reading, repeated reading, effort to imitate both in written and oral form" (my translation).

100 Fiévet (2015: 309 with n. 2): "Altera autem ex parte, cur qui Latinum sermonem docent iis commoditatibus diutius abstineant quae a doctis illis recentioribus in "linguistica" quam "structuralem" vocant versatis allatae sunt, cum omnibus constet artem vivarum linguarum docendarum illorum inventis quasi novo impetu roboreve auctam esse?" C. Fiévet is a great promoter of the so-called audio-oral method. Malkusová (2012: 60) defines it as follows: "The method is based on behavioristic psychology and, in many ways, it is a continuation of so called direct method. New materials are presented in the form of a dialogue which is designed according to the principles of learning a foreign language by habits. The individuals repeat a sequence of several sentences over and over again. Individual structures of a language are learned simultaneously with the help of drill exercises. Usually, grammar is not explained. Individual phases of teaching are: listening, speaking, reading, and at the very end, writing. Vocabulary is limited and it is always presented in context. Good pronunciation is stressed significantly" (my translation). Cf. Tagliaferro (2003: 68) and Ricucci (2015: 22), who speaks of "situational approach".

101 See e.g. Ball, Ellsworth (1996). 
A compromising position is taken by, among others, Terence Tunberg, who "argues that a classical language instruction must nevertheless differ from that of modern, national vernacular tongues. He points out that the structure and therefore the standards of correct expression are fixed in model texts, and are not evolving in Latin as they do in the national languages, and that Latin teachers aim more exclusively at the reading and understanding of literature and do so sooner in the teaching process than their colleagues in the modern languages. He is also convinced that many activities currently taken for granted in classical language pedagogy, including conventional exercises that emphasize syntax and grammar, are fully consistent with active Latin and can be profitably used in combination with the constant engagement of students in the target language." 102 Claude Pavur also offers a neat assessment of the state of affairs: "There is the Philological Model, which ... stands over against the Humanist Model ... I set forth these models as heuristically valuable "ideal types." Though they do tend to move in different directions, they are not contradictory or mutually exclusive. Though there is in fact a complementarity to these two approaches that calls for more sophisticated collaboration between them, both have a certain claim to priority that can be defended by their partisans. Both are useful. If one has just discovered a papyrus fragment with Latin writing on it, then one probably wants the hard-core linguistic knowledge of the classical philologist. But if one has five hundred pages of Petrarchan Latin to negotiate, the most refined knowledge of grammar will be to little avail if one's lack of practice has condemned one to read at an unbearably slow speed. Life is simply too short." 103

In any event, it seems that the active approach, which can (as we can see below) very well use coll. from a set of the $H$., works and gains considerable popularity despite various objections. Neil Coffee promotes the active language instruction, including written and spoken manifestations, and states that "although we still await studies that fully substantiate this claim, the endorsement of such a combined approach as one legitimate method by educational bodies in the U.S. demonstrates that at least some educators are persuaded of its efficacy." 104 The qualities and merits of the active approach have also been validated, through her own experience, by the director of the American Council on the Teaching of Foreign Languages, Martha G. Abbott: "The surprising result for me as a teacher is that my own reading and understanding of Latin increased after that experience. There were obviously other senses and skills that I had never used to reinforce my own comprehension of the language, skills that took me from simply translating to really being able to read Latin. If we expect our students to develop true reading ability in Latin, we must use whatever learning modes work best for them." 105 M. Abbott in her defence of the active

102 Coffee (2012: 266).

103 Pavur (1998).

${ }^{104}$ Coffee (2012: 256). It was already in 1985 that The New York State Board of Regents produced a Latin syllabus, based on current second language acquisition research that stresses functional communication skills rather than traditional linguistic elements. The focus of the syllabus is direct communication from the ancient to the modern world through reading skills, supported by writing and, to a lesser extent, by listening and speaking skills ... For more see: http://eric.ed.gov/?id=ED266675 (29 March 2017). And Coffee (2012: 264) himself adds: "But I have also seen how speaking and writing Latin can bring a much deeper and more fluent knowledge of the Latin idiom that not only significantly improves reading comprehension - ultimately the primary first-order aim of Latin instruction - but itself forms part of the bedrock of cultural understanding that is the larger goal of classical studies."

105 Abbott (1998: 38). 
approach also writes that if Latin had not been taken as a regular second (living) language with all its methods, it would likely not have been included in general curriculum by authorities and its already weak position would become even weaker. ${ }^{106}$ This measure could raise suspicions of making a virtue out of necessity, but it has been shown quite extensively above that a living approach to Latin is not reprehensible.

I can thus perhaps join T. Tunberg and C. Pavur and conclude this passage recapitulating the most frequently used methods by stating that each method can find its application. It greatly depends on the conditions of its usage, type of students and the phase of the learning process when it is used. The variety and diversity of methods, approaches and exercises is, after all, emphasized by A. Deagon in her treatise on various types of students and their preferences and needs. ${ }^{107} \mathrm{I}$ join N. Coffee in a conclusion that so far we do not have a sufficient amount of feedback and evidence from concrete learning environments (in particular from those with limited number of lessons), on the basis of which one could make definitive conclusions.

\section{Conclusion: natural method and the Hermeneumata Pseudodositheana}

The overview of the structure, content, and didactic goals discussed in examples from coll. leads to the conclusion that $H$. and especially their coll., which were used in the lower grades of the educational system, were a proven teaching aid, and that the lessons themselves were executed along the lines of what now would be called the natural method. The examples also confirm that at the core of learning is apparently the lexicon and phraseology in reference to morphology. Syntax was left somewhat aside. It is also this that brings the method of the coll. together with the natural method. It seems that the approach of the coll. was fairly effective in ancient times: students enjoyed it, and they were achieving good results with its help. Had it not been so, $H$. would not have existed for several centuries and they would have not been an inspiration for the Middle Ages, Renaissance, and the modern era.

If coll. were so successful in the past, we can use them as a supportive means when teaching by natural method even today. E. Dickey presents a testimony of their successful application even at a university level. ${ }^{108}$ It is necessary, however, to be cautious and to implement them in lessons with a proper commentary (on, for example, the non-normative character of their grammar).

Critics of natural method and productive Latin teaching argue that made-up texts which are used in the first phases of direct method teaching are non-authentic, harmful and may make a false impression about the proper form of Latin. ${ }^{109}$ A. Deagon also

106 Abbott, Davis (1996: 85).

${ }^{107}$ Deagon (2006: 45).

${ }^{108}$ Dickey (2012: xi) and (2015b: 37, n. 12): "I have used slightly adapted extracts from the Latin half of the colloquia with a first-year Latin class at the University of Exeter and found the material to be excellent for modern students, provided the vocabulary is adequately glossed." Effectiveness in the lesson has been confirmed also by Corbeill (2013).

${ }^{109}$ Deagon (1991: 65), however, writes: "The desire to avoid "made-up" Latin has been generally recognized as counterproductive in elementary language learning, but this realization has not generally 
urges for the use of authentic ancient materials suitable for beginners: "In both ancient and modern languages, these materials provide the students with real contact with the culture whose language they are studying. In modern languages, though, the primary lesson information matches up more closely with these items: i.e., since students may have a lesson whose vocabulary focuses on food and how to get it, reading a menu is closer to the skills they are actually learning. The Latin equivalent, such as reading graffiti or inscriptions, takes special teaching. Yet it is real communication with the past and does have a place in the elementary classroom." 110 New edition of coll. from $H$. offers other and even more complex didactic tool of this kind. Coll. both are and are not an authentic text: they undoubtedly imitate a real conversation, yet they were clearly compiled with a didactic aim. Still, it is perhaps not entirely off-topic to have a look at them if we want our students to move to reading texts as soon as possible. Coll. are also closely connected to the everyday reality of the ancient times and they can, to some extent, bring this reality closer to the imagination of contemporary students.

We can see several uses of the coll. on the selected excerpts when teaching Latin following a natural and active method: if we discuss the Roman education system, we can read with the students how it is described by a real Roman pupil. Students will not only learn something about specific teaching practices but they will also acquire relevant word-stock. Further part of the coll. can be adapted for simple sketches that will not lack the authenticity of ancient environment. A play as a means of teaching, as advised by Quintilian and Comenius, is a great tool for gaining students' attention and interest. We can give them a task, for example, to come up and write a similar berating scene, as is in excerpt 6). Older and more experienced students can "think through" and complete an incomplete utterance from example 4). On another occasion they can be entrusted with the task to describe their own wake-up routine (or another daily routine) and with using vocabulary from example 5), or can look up new words to reflect current conventions. They can also describe a different part of the day or a different activity etc. There is an infinite potential of usage (and I have shown only several pieces of coll. in this paper) and the work with the coll. will always have a hallmark of authenticity. By using an example of coll. we at the same time stick to the principle applied in the ancient rhetorical progymnasmata: "studying what people naturally do."111 A problem might occur because some coll. texts were aimed at younger children. Students nowadays study Latin when they are older and their perception of the world is naturally different from children. However, I know from experience that with a certain detached view and with the right motivation, even more mature students are willing to work with texts aimed at younger children and draw useful knowledge and pleasure from them.

affected the exercises textbooks present" and Johnson (1987: 247-248) indicates that "teachers of modern languages, on the other hand, have access to a wealth of simple, yet authentic contemporary texts, including articles from newspapers and magazines, short fiction, and even comic books, all of which can be used to provide relatively rapid and interesting reading material for the intermediate-level language class. Modern language students typically go five semesters before encountering their first literary text (usually a contemporary author) and six or seven semesters before tackling a classic literary text, such as Voltaire or Racine, comparable to those we customarily put in students' hands (often, without sufficient vocabulary aids) as early as the third college semester, if not sooner."

110 Deagon (1991: 68-69).

111 Baxter (2008: 7). 
Perhaps we could create a textbook or, at least, an instruction manual in which we could implement the coll. or their paraphrases. ${ }^{12}$ With such textbook and with the introduction of a living component into the teaching process, one could gradually, provided that there will be sufficient number of Latin lessons, arrive at what John Gruber-Miller describes: "As our students become more conversant in simple Latin conversations (for example with the help of the coll.), listen to mythological narratives, and present skits and fabellae, they become more comfortable with the rhythms, sounds, and verbal patterns in Plautus' wordplays, Catullus' meters, Cicero's arguments, and Petronius' narratives." 113

As to the coll. from the set of $H$., it is obvious that these were designed for encouraging the wider public to engage with the ancient languages, as is evident from the use of undemanding texts, every day practical focus etc. Many current methodologists and other classical philologists speak out against an elitist conception of classics and strive for (for the sake of self-preservation) new ways into the classics for people beyond those who focus on the classics professionally. I believe that the active approach, eventually supported by the use of such authentic texts like the coll., makes this wider scope possible and discourages students from leaving Latin studies in the initial stages disgusted or devastated by its demanding grammar and dry approach.

We adopt many models from various fields of classics. Therefore, it may prove fruitful to borrow from antiquity this demonstrably useful aid - the principles of which have already been re-discovered through the direct or natural method of teaching a foreign language and in textbooks based on this approach. ${ }^{114}$

Overall, coll. established a significant tradition in didactic literature and prepared the ground for more elaborate dialogues, which were created as teaching aids in the Middle Ages and during the Renaissance. Examples of these include the collection De aliquibus raris fabulis (perhaps from around the $5^{\text {th }}$ century $\mathrm{AD}$ ) or the colloquia by Aelfric of Winchester and Aelfric Bata (the $10^{\text {th }}$ and $11^{\text {th }}$ century AD). The peak of the form is represented by the sophisticated and linguistically elaborate dialogues of Erasmus of Rotterdam and Johann Reuchlin. Development of the form then continued into the modern era. ${ }^{115}$

\section{REFERENCES}

Abbott, M. G., 1998. 'Trends in Language Education: Latin in the Mainstream'. In: R. A. LaFleur (ed.), Latin for the 21 ${ }^{\text {st }}$ Century: From Concept to Classroom. Glenview: Scott Foresman / Addison Wesley, 38.

112 Pavur (1998): "It does not seem to me utopian to suggest the development of introductory textbooks that would help students to read and to produce many times what they might tend to average in most programs today. Many short, simple, phrases and sentences can get us there, perhaps in conjunction with something that will increase linguistic experience considerably: using Latin as the language of communication in class."

${ }^{113}$ Gruber-Miller (2005: 88).

${ }^{114}$ Dickey (2015b: 38) points out that all ancient course books are written in the language they teach. We can see these parallels, for example, in the course books by H. H. Ørberg. In March 2016, Eleanor Dickey published a book called Learning Latin the Ancient Way. Latin Textbooks from the Ancient World. Unfortunately, I did not have a chance to study this publication, which no doubt brings many important and useful findings about teaching by means of $H$. and their coll., before submitting this paper.

${ }^{115}$ Cf. Gwara (2002). 
Abbott, M. G., Davis, S., 1996. 'Hyperreality and the Study of Latin: Living in a Fairy Tale World'. The Modern Language Journal 80, 85-86.

Adams, J. N., 2003. Bilingualism and the Latin Language. Cambridge: Cambridge University Press.

Allinson, A. R. (transl.), 1930. The Satyricon by Petronius. New York: The Panurge Press.

Anhalt, E., 2006. 'Translation and Interpretation for Intermediate and Advanced Students'. The Classical World 100, 45-48.

Ball, R. J., Ellsworth, J. D., 1989. 'Against Teaching Composition in Classical Languages'. The Classical Journal 85, 54-62.

Ball, R. J., Ellsworth, J. D., 1992. 'Flushing out the Dinosaurs: Against Teaching Composition II'. The Classical Journal 88, 55-65.

Ball, R. J., Ellsworth, J. D., 1996. 'The Emperor's New Clothes: Hyperreality and the Study of Latin'. The Modern Language Journal 80, 77-84.

Baxter, N. S., 2008. The Progymnasmata: New/Old Ways to Teach Reading, Writing, and Thinking in Secondary Schools. Diploma thesis. Brigham Young University, Provo. http://scholarsarchive.byu.edu /etd/1523/ [29 March 2017].

Bexley, E., 2015. 'Ludic Lessons: Roman Comedy on Stage and in Class'. The Classical Journal 111, 112125.

Bloomer, W. M., 2011. 'Quintilian on the Child as a Learning Subject'. The Classical World 105, 109-137.

Blum, E., 2008. 'The New Old Way of Learning Languages'. The American Scholar, https://theamericanscholar.org/the-new-old-way-of-learning-languages [29 March 2017].

Coffee, N., 2012. 'Active Latin: Quo tendimus?'. The Classical World 105, 255-269.

Corbeill, A., 2013. 'Eleanor Dickey, The Colloquia of the Hermeneumata Pseudodositheana. Volume 1: Colloquia Monacensia-Einsidlensia, Leidense-Stephani, and Stephani'. Bryn Mawr Classical Review 2013.08.34. http://bmcr.brynmawr.edu/2013/2013-08-34.html [29 March 2017].

Cribiore, R., 1996. Writing, Teachers, and Students in Graeco-Roman Egypt. Atlanta: Scholars Press.

Cribiore, R., 2001. Gymnastics of the Mind: Greek Education in Hellenistic and Roman Egypt. Princeton: Princeton University Press.

Deagon, A., 1991. 'Learning Process and Exercise Sequencing in Latin Instruction'. The Classical Journal 87, 59-70.

Deagon, A., 2006. 'Cognitive Style and Learning Strategies in Latin Instruction'. In: J. Gruber-Miller (ed.), When Dead Tongues Speak: Teaching Beginning Greek and Latin. Oxford: Oxford University Press, 27-49.

Debut, J., 1984. 'Les Hermeneumata Pseudodositheana. Une méthode d'apprentissage des langues pour grands débutants'. Koinonia 8, 61-85.

Dickey, E., 2012. The Colloquia of the Hermeneumata Pseudodositheana. Colloquia Monacensia-Einsidlensia, Leidense-Stephani, and Stephani from the Hermeneumata Pseudodositheana. Edited with introduction, translation, and commentary by E. Dickey. Cambridge: Cambridge University Press.

Dickey, E., 2015a. The Colloquia of the Hermeneumata Pseudodositheana. Volume II. Colloquium Harleianum, Colloquium Montepessulanum, Colloquium Celtis, and Fragments. Edited with translation and commentary by E. Dickey. Cambridge: Cambridge University Press.

Dickey, E., 2015b. 'Teaching Latin to Greek Speakers in Antiquity'. In: E. P. Archibald, W. Brockliss, J. Gnoza (eds.), Learning Latin and Greek from Antiquity to the Present. Cambridge: Cambridge University Press, 30-51.

Dionisotti, A. C., 1982. 'From Ausonius' Schooldays? A Schoolbook and Its Relatives'. The Journal of Roman Studies 72, 83-125.

Ferri, R., 2010. 'Textual and Linguistic Notes on the Hermeneumata Celtis and the Corpus glossariorum' . Classical Quarterly 60, 238-242.

Fiévet, C., 2015. 'Quemadmodum usus sermonis Latini in schola viam ad legendum planiorem brevioremque aperire possit'. Mantinea 1, 305-327.

Flammini, G., 2004. Hermeneumata Pseudodositheana Leidensia. Edidit G. Flammini [Bibliotheca scriptorum Graecorum et Romanorum Teubneriana]. Monachii / Lipsiae: K. G. Saur.

Goetz, G., 1892. Corpus Glossariorum Latinorum. Vol III. Hermeneumata pseudodositheana. Accedunt hermeneumata medicobotanica vetustiora. Edidit G. Goetz. Lipsiae: Teubner. 
Gruber-Miller, J., 2005. 'Developing Listening and Speaking Skills: Practical Ways to Implement the Standards with the "Oxford Latin Course". The Classical Journal 101, 87-98.

Gwara, S., 2002. 'The Hermeneumata pseudodositheana, Latin Oral Fluency, and the Social Function of the Cambro-Latin Dialogues Called De raris fabulis'. In: C. D. Lanham (ed.), Grammar and Rhetoric: From Classical Theory to Medieval Practice. London: Continuum Books, 109-138.

Hagendahl, H., 1967. Augustine and the Latin Classics. Göteborg: Acta Universitatis Gothoburgensis.

Hansen, W. S., 2000. 'Teaching Latin Word Order for Reading Competence'. The Classical Journal 95, 173-180.

Johnson, J. F., 1987. 'Alternative Approaches for the College Elementary Latin Sequence'. The Classical Journal 82, 246-255.

Johnson, W. A., 2011. 'Teaching the Children How to Read: The Syllabary'. The Classical Journal 106, 445-463.

Korhonen, K., 1996. 'On the Composition of the Hermeneumata Language Manuals'. Arctos. Acta philologica Fennica 30, 101-119.

Krčmová, M., Chloupek, J., 2002. 'Jazyk národní' [National language]. In: P. Karlík, M. Nekula, J. Pleskalová (eds.), Encyklopedický slovník češtiny [Encyclopedic dictionary of Czech]. Praha: Nakladatelství Lidové noviny, 192-194.

Levine, M., 2006. 'Oracles of a Quadragenarian Latin Teacher'. The Classical World 100, 49-53.

Malkusová, L., 2012. Vzdělávání dospèlých v oblasti cizích jazyků v Českých Budějovicích [Education of Adults in the Area of Foreing Languages in České Budějovice]. Diploma thesis. Jihočeská univerzita v Českých Budějovicích, Teologická fakulta. http://theses.cz/id/dr24y2/Diplomka_k_tisku2.pdf [29 March 2017].

Markus, D. D., Ross, D., 2004. 'Reading Proficiency in Latin through Expectations and Visualization'. The Classical World 98, 79-93.

Miraglia, L., 1996. 'Come (non) si insegna il latino'. Micromega 5, 1-14.

Miraglia, L., 2004. 'La didattica del greco e del latino nell'impero romano: aspetti tecnici e culturali'. In: S. Medaglia (ed.), Miscellanea in ricordo di A. R. Sodano. Napoli: Guida, 207-238.

Miraglia, L., 2009. Nova via, Latine doceo: guida per gli insegnanti. Parte I, Familia Romana. Roma: Edizioni Accademia Vivarium novum.

Pavur, C., 1998. 'Upgrading Latin Pedagogy'. Electronic Antiquity 4/2, https://scholar.lib.vt.edu/ejournals /ElAnt/V4N2/pavur.html [29 March 2017].

Penella, R. J., 2011. 'The Progymnasmata in Imperial Greek Education.' The Classical World 105, 77-90.

Pucci, J., 2009. 'Ausonius' Ephemeris and the Hermeneumata Tradition'. Classical Philology 104, 50-68.

Ricucci, M., 2015. L'apprendimento delle lingue classiche nella prospettiva della Second Language Acquisition. Tesi di dottorato di ricerca. Università degli studi di Udine. https://dspace -uniud.cineca.it/handle/10990/532 [29 March 2017].

Rochette, B., 1997. Le latin dans le monde grec. Recherches sur la diffusion de la langue et des lettres latines dans les provinces hellénophones de l'Empire romain. Bruxelles: Latomus.

Rochette, B., 2008. 'L'enseignement du latin comme L 2 dans la Pars Orientis de l'Empire romain : les Hermeneumata Pseudodositheana'. In: F. Bellandi, R. Ferri (eds.), Aspetti della scuola nel mondo romano. Amsterdam: Hakkert, 81-109.

Stramaglia, A., 1996. 'Fra "consumo" e "impegno": usi didattici della narrativa nel mondo antico'. In: O. Pecere, A. Stramaglia (eds.), La letteratura di consumo nel mondo greco-latino. Atti del convegno internazionale. Cassino: Edizioni Università di Cassino, 97-166.

Stramaglia, A., 2010. 'Come si insegnava a declamare? Riflessioni sulle "routines" scolastiche nell'insegnamento retorico antico'. In: L. Del Corso, O. Pecere (eds.), Libri di scuola e pratiche didattiche. Dall' antichità al Rinascimento. Atti del Convegno Internazionale di Studi. Cassino: Edizioni Università di Cassino, 111-151.

Tagliaferro, E., 2003. 'Gli Hermeneumata. Testi scolastici di età imperiale trainnovazione e conservazione'. In: M. S. Celentano (ed.), Ars / Techne. Il manuale tecnico nelle civiltà greca e romana. Alessandria: Edizioni dell'Orso, 51-77.

Thomson, A. (transl.), 1909. The Lives of the Twelve Caesars by C. Suetonius Tranquillus, to which are added His Lives of the Grammarians, Rhetoricians and Poets. London: George Bell \& Sons.

Wills, J., 1998. 'Speaking Latin in Schools and Colleges'. The Classical World 92, 27-34. 


\title{
HERMENEUMATA (PSEUDODOSITHEANA) \\ A JEJICH DIDAKTICKÉ VYUŽITÍ
}

Článek podává základní charakteristiku latinsko-řeckých didaktických textů zvaných Hermeneumata Pseudodositheana a zejména jejich colloquií. Přináší několik ukázek colloquií se stručným komentářem a rozborem zaměřeným zvláště na jejich didaktickou stránku. Ve druhé části př́spěvku se pozornost věnuje rozdílu mezi aktivním a pasivním přístupem $\mathrm{k}$ výuce klasických jazyků, $\mathrm{z}$ teoretického i praktického hlediska, a hledaní styčných bodů mezi metodou antických colloquií a metodami moderními. Následuje teoretické zdůvodnění možnosti využití colloquií při výuce latiny přirozenou / přímou metodou spolu s několika návrhy, jak tyto texty mohou přispět k efektivnosti i atraktivitě dnešní výuky latiny.

\author{
Bořivoj Marek \\ Charles University, Prague \\ borivoj.marek@ff.cuni.cz
}

